\title{
Surveillance of deaths on board Danish merchant ships, 1986-93: implications for prevention
}

\author{
Henrik L Hansen
}

\begin{abstract}
Objective-To describe and analyse the types and circumstances of all natural and non-natural deaths among seamen on board Danish merchant ships.

Methods-Data on 147 cases were obtained from maritime authorities, an insurance company, shipping companies, hospitals, death registers, and death certificates in the period from 1986-93.

Results-The 53 natural deaths were dominated by cardiovascular diseases and infectious diseases. Insufficient treatment on board was identified as a contributing factor for death in some cases. Medical advice was not always sought and the advice given was in some cases insufficient. 73 fatal accidents were identified. The incidence of accidents of $5 \cdot 29 / 10000$ person-years was 11.5 times higher than the incidence of $0 \cdot 46 / 10000$ for the Danish male workforce ashore. 23 accidents (31\%) were due to maritime casualties and $26(36 \%)$ were occupational accidents. The remaining 24 (33\%) were accidents during off duty hours including six self intoxications. Rough weather, inadequate awareness of safety, lack of use of personal protection devices, and inexperience were associated with many of the fatal injuries directly related to work. Alcohol played a major part in 12 out of 18 fatal injuries occurring during off duty hours.

Conclusions-The maritime workplace was identified as a high risk workplace and in many aspects differs from the conditions ashore. Acute diseases and serious injuries pose special risks to seamen because of a lack of direct access to professional medical care at sea. Primary prevention of certain diseases is needed and possible. Improved training, improved systems of work, improved safety awareness, and greater use of personal protection devices are needed to prevent fatal injuries. Medical training of ships' officers providing medical care on board and specific training of doctors giving medical advise to ships should be improved to meet the needs.
\end{abstract}

(Occup Environ Med 1996;53:269-275)

Keywords: occupational fatalities; maritime medicine; accidents
Merchant seamen are exposed to some hazards rarely encountered in other occupations, including water, extremes of weather, as well as more widespread hazards such as a lot of mechanical equipment and toxic cargoes. ${ }^{1-4}$ Travel to many different parts of the world may cause exposure to infectious agents not prevalent or non-existing in the homeland of the seaman. Also, at sea there is a lack of direct access to qualified medical assistance to handle accidents or cases of serious illness. . $^{5-7}$

The maritime industry is important in all Scandinavian countries, and Denmark alone has a merchant navy employing more than 15000 registered seamen mainly on ships engaged in foreign trade all over the world. About another 5000 seamen are employed in smaller vessels in domestic trade, on board tugs, and in domestic ferry traffic.

To identify areas for possible interventions, a study was designed to identify all deaths, natural and non-natural, on board Danish merchant ships and gather all possible details about the circumstances under which the death took place.

\section{Materials and methods}

INCLUSION CRITERIA

Included in the study were all deaths among crew signed on privately owned Danish commercial ships except fishing vessels. Also seamen who died ashore within 30 days after leaving a ship because of acute disease on board. Deaths after an accident on board were included. Two young men signed on as supernumerary crew were included. Deaths among seamen signed on a ship but on leave, passengers, stowaways, and deaths on board government owned ships, naval ships, and leisure boats were not included. The study period was eight years from January 1986 to December 1993.

\section{SUBJECTS}

In the case of a death on board a Danish merchant ship the captain is obliged to notify the Danish Maritime Authority. The Danish government covers all medical expenses of seamen while they are abroad and if a seaman dies while in service outside Denmark; the maritime authorities will also pay the expenses and may in this way get knowledge of a death not notified directly. In every case, a file is made where all the documents from the case are gathered. In total 397 files from the study period were reviewed and 138 deaths fulfilling 
the criteria for inclusion were identified. The rest were fishermen or seamen who had died while on leave.

In the study period, one insurance company (Danish Shipowners Accident Insurance Association) had a monopoly and obligation to insure all seamen on board Danish commercial ships. By reviewing all claims in the study period, a further six deaths were identified.

All seamen and each engagement period in Danish registered privately owned merchant ships over 20 gross registered tons (GRT) are, with few exceptions, recorded in a database in the Danish Maritime Authority called the Register of Seafarers. The database was linked with the Danish Civil Register to identify all deaths. All deaths which had occurred within 30 days of having left a job on board a ship were further investigated. Three more deaths were identified in this way, all on board ships in domestic trade.

After the identification of all deaths, further information about the cases was sought in the files of the Danish Maritime Authority, the insurance company, the National Board of Industrial Injuries, Danish hospital records, and from documents requested from shipping companies. Further, the personal identification numbers of the dead were linked with the Register of Causes of Death at the Danish National Board of Health and 109 of the 147 cases $(74 \cdot 1 \%)$ were identified in the register and a copy of the death certificate was requested.

Manner and causes of death were found from the available sources with assistance from the Department of Forensic Medicine, University of Aarhus, Denmark. The sources of information were maritime inquiries, ships' log books, telex communications, death certificates, necropsy reports, police reports, case records, bills, reports from captains, notifications to the maritime authorities, and other documents. More than 2000 documents from 27 different countries were available.

Among 53 seamen who died of natural causes, information about results of necropsies existed in 43 cases or $81.2 \%$. In four of the remaining cases hospital documents or documents referring to hospital documents about diagnosis were available. In the remaining six cases, the diagnosis was based on captains reports, maritime inquiries, copies of ships log book, and death certificates based on clinical data only. One of the six was buried at sea. In 14 out of 73 cases $(19.2 \%)$ where the cause of death was an accident, a necropsy was performed. In five of six cases where the cause of death was accidental intoxication, information from a necropsy was available. In the last case of intoxication, a police report gives good evidence about the type of intoxication. Among the 59 deaths caused by accidents where an necropsy was not performed, the seamen had drowned and the body was not recovered in 31 cases $(52 \cdot 5 \%)$. None of the seven cases where the manner and cause of death could not be determined had a necropsy performed. Six out of the seven had disappeared at sea or in port. None of those who committed suicide or were killed had a necropsy performed.
DENOMINATOR DATA

To compare the number of traumatic fatalities on board merchant ships with the number in other industries in Denmark, the total number of registered seamen each year during the study period was found from the Register of Seafarers which was computerised in April 1986. Only seamen recorded in April 1986 or later were included and all were counted as if they were employed and thus at risk during the whole year except for the year 1986 where they only contributed nine months. In total, there were 104000 person-years at risk. The number of years at risk for the whole population was based on official statistics on number of active people in the workforce each year from 1986 to 1993 and totalled 11678686 person-years at risk. ${ }^{8}$ All who had been working in one calendar year were counted as if they had been at risk for the whole year. The data are based on the number economically active in the last week of November each year and include self employed people and people who were temporarily absent because of disease or leave. ${ }^{9}$

\section{STATISTICS}

Data were analysed with EPI-Info version $6.02 .^{10} 95 \%$ Confidence intervals (95\% CIs) were calculated from the methods of Greenland and Robins. ${ }^{11}$

ETHICS

This study was approved by the regional Ethics Committee.

\section{Results}

A total of 147 deaths, five women and 142 men, were identified, of which 53 were natural deaths, 73 were fatal injuries, 12 were suicide, two were murdered, and in the remaining seven cases, manner of death could not be found. In six of them the seamen had disappeared at sea or in port, and in the last case a young seaman died suddenly, but this case was not investigated in detail. One hundred and nineteen $(81 \%)$ were Danish citizens, the remaining 28 seamen were of 13 different nationalities, and 133 (90\%) were known in the Register of Seafarers. Twenty two deaths $(15 \%)$ took place in Danish territorial waters or in a Danish port (including Greenland), the rest on board ships and in ports all over the world.

\section{NATURAL DEATHS}

Table 1 shows the causes of death among the 53 seamen who died of natural causes. Among the 31 seamen who died on board while the ship was at sea, 13 were found dead without symptoms of disease known to others on board, and five died within minutes after an acute heart attack or sudden cardiac arrest.

Among the eight cases of infectious diseases were three cases of malaria, three cases of pneumonia, one case of meningitis, and one case of acute laryngitis giving obstruction of the airways. The gastrointestinal diseases included four cases of gastrointestinal bleeding 
Table 1 Causes of deaths among seamen dying of natural causes in relation to location of ship on discovery of disease and location of death

\begin{tabular}{|c|c|c|c|c|c|c|}
\hline \multirow[b]{3}{*}{ Final diagnosis } & \multirow[b]{3}{*}{ Total } & \multirow{2}{*}{\multicolumn{2}{|c|}{$\begin{array}{l}\text { Location of ship on } \\
\text { discovery of disease }\end{array}$}} & \multicolumn{3}{|c|}{$\begin{array}{l}\text { Location of the deceased at } \\
\text { time of death }\end{array}$} \\
\hline & & & & \multicolumn{2}{|c|}{ On board } & \multirow[b]{2}{*}{ Ashor } \\
\hline & & At sea & $\begin{array}{l}\text { At berth/ } \\
\text { the roads }\end{array}$ & At sea & $\begin{array}{l}\text { At berth/ } \\
\text { the roads }\end{array}$ & \\
\hline Infectious diseases & 8 & 7 & 1 & 5 & 0 & 3 \\
\hline Gastrointestinal diseases & 6 & 6 & 0 & 5 & 0 & 1 \\
\hline Heart diseases & 29 & 19 & 10 & $17^{\star}$ & 6 & 6 \\
\hline Cerebrovascular stroke & 6 & 4 & 2 & $2 \dagger$ & 1 & 3 \\
\hline Other diseases & 4 & 2 & 2 & $2 \dagger$ & 1 & 1 \\
\hline Total & 53 & 38 & 15 & $31 \mp$ & 8 & 14 \\
\hline
\end{tabular}

*Including 11 seamen found dead without any previous symptoms known to other crew members.

†Including one seaman found dead without any previous symptoms known to other crew members.

fIncluding 13 seamen found dead without any previous symptoms known to other crew members.

and two cases of gastrointestinal perforations. Among the 29 who died because of heart disease, 23 had a necropsy performed which showed that all except two had ischaemic heart disease. Other diseases included one case of alcohol withdrawal symptoms, one case of dissecting aortic aneurism, one case of pulmonary thromboembolism, and in one case no cause of death was found despite necropsy.

ACCIDENTS AND OTHER NON-NATURAL DEATHS The fatal accidents can be divided into three main groups (tables 2 and 3). Maritime disasters include shipwreck, capsizing, explosion, and fire on board. Nineteen of the 23 lives lost because of maritime disasters were due to the loss of five coasters. The remaining casualties were due to the loss of a suction dredger, a small tug, and a stone transport vessel. The Danish Maritime Authorities carry out detailed investigations of the causes and prevention of maritime disasters. ${ }^{12}$

Occupational accidents are in this paper defined as accidents occurring while the seaman was on duty and the accident occurred as a direct consequence of the work. A total of 26 fatal occupational accidents were identified (table 2 and 3). Falls on board were the cause of five fatal accidents. One seaman fell down from a mast and was not using a safety belt. Another fell into the water while securing a gangway, and the remaining three fell down stairs, from a container, and from a tween deck. Falls overboard happened in two cases during preparations for setting out a pilot ladder over the ships' side. Both seamen were working alone. In the last case, the seaman fell overboard from a lifeboat used for transport. One of the eight victims of falls was according to statements in the maritime inquiry under the influence of alcohol and another was proved to be inebriated. One seaman had diabetes, one had a history of recent convulsions, and one had a history of recent drug misuse.

Five seamen were lost because they were swept overboard while working on deck in bad weather. They were securing loose oil drums, wires, and other detached material. None of them used safety lines or life jackets. All three seamen killed during mooring operations were hit by a hawser, in two cases because the hawser burst. The three lives lost because of suffocation were seamen who had entered a hold or tank to do some work. Oxygen content was not checked before entering in any of the cases and safety lines were not used, which delayed the rescue in all three cases. One death in an engine room was due to an explosion in a centrifuge, the other was caused by an explosion of a steam tube. Among the remaining accidents, two were traffic accidents which happened on board roll-on roll-off (RoRo) ships. The remaining three casualties were caused by a falling object in two cases and the last was a diver who lost his life while diving.

The mean age of the seamen who lost their lives due to occupational accidents was 35.5 (18-55) years or about the same as the mean age of all seamen on board Danish ships. Six of the 26 had less than two years of experience at sea. Five of these were fulfilling duties they were directly ordered to do and in four of

Table 2 Causes of deaths among seamen dying of non-natural causes in relation to location of ship on time of accidents and location of the deceased at the time of death

\begin{tabular}{|c|c|c|c|c|c|c|}
\hline \multirow[b]{3}{*}{ Type of accident } & \multirow[b]{3}{*}{ Total } & \multirow{2}{*}{\multicolumn{2}{|c|}{$\begin{array}{l}\text { Location of ship } \\
\text { at time of accident }\end{array}$}} & \multirow{2}{*}{\multicolumn{2}{|c|}{$\begin{array}{l}\text { Location of the deceased at } \\
\text { time of death } \\
\text { On board }\end{array}$}} & \multirow[b]{3}{*}{ Ashore } \\
\hline & & & & & & \\
\hline & & At sea & $\begin{array}{l}\text { At berth/ } \\
\text { the roads }\end{array}$ & At sea & $\begin{array}{l}\text { At berth/ } \\
\text { the roads }\end{array}$ & \\
\hline $\begin{array}{l}\text { Occupational accidents } † \\
\text { Maritime disasters } \ddagger \\
\text { Other accidents } \\
\text { Murder } \\
\text { Suicide } \\
\text { Unknown manner of death } \\
\text { Total }\end{array}$ & $\begin{array}{r}26 \\
23 \\
24 \\
2 \\
12 \\
7 \\
94\end{array}$ & $\begin{array}{r}11 \\
23 \\
5 \\
1 \\
8 \\
6 \\
54\end{array}$ & $\begin{array}{r}15 \\
0 \\
19 \\
1 \\
4 \\
1 \\
40\end{array}$ & $\begin{array}{r}11 \\
23 \\
4 \\
1 \\
8 \\
6 \\
53\end{array}$ & $\begin{array}{r}9 \\
0 \\
3 \\
0 \\
4 \\
0 \\
16\end{array}$ & $\begin{array}{r}6 \\
0 \\
17 \\
1 \\
0 \\
1 \\
25\end{array}$ \\
\hline
\end{tabular}

*Including seamen lost from the ship.

† Accidents occurring as a direct consequence of work on board.

fDeaths caused by shipwreck or capsizing.

SAccidents occurring during off duty hours (see table 3 for details). 
Table 3 Accidents according to description among different categories of seamen (n(\%))

\begin{tabular}{|c|c|c|c|c|c|c|}
\hline \multirow[b]{3}{*}{ Description } & \multicolumn{6}{|c|}{ Charge on board } \\
\hline & \multirow{2}{*}{$\begin{array}{l}\text { Ships } \\
\text { officers }\end{array}$} & \multirow{2}{*}{$\begin{array}{l}\text { Ships } \\
\text { engineers }\end{array}$} & \multicolumn{2}{|c|}{ Deck crew } & \multirow{2}{*}{$\begin{array}{l}\text { Other } \\
\text { crew }\end{array}$} & \multirow{2}{*}{$\begin{array}{l}\text { Total } \\
(n(\%))\end{array}$} \\
\hline & & & $A B$ & OS & & \\
\hline \multicolumn{7}{|l|}{ Maritime casualties: } \\
\hline $\begin{array}{l}\text { Ship sank or capsized } \\
\text { Occupational accidents: }\end{array}$ & 9 & 2 & 2 & 5 & 5 & $23(32)$ \\
\hline \multicolumn{5}{|l|}{ Occupational accidents: } & 0 & \\
\hline Swept overboard & 2 & 0 & $\begin{array}{l}1 \\
2\end{array}$ & 0 & 2 & $5(7)$ \\
\hline Fell overboard & 0 & 0 & 2 & 1 & 0 & $3(4)$ \\
\hline Mooring operations & 0 & 0 & 2 & 1 & 0 & $3(4)$ \\
\hline Suffocation in holds and tanks & 1 & 0 & 0 & 2 & 0 & $3(4)$ \\
\hline Accidents in engine rooms & 0 & 2 & 0 & 0 & 0 & $2(3)$ \\
\hline Other accidents & 1 & 1 & 1 & 0 & 2 & $5(7)$ \\
\hline \multicolumn{7}{|l|}{$\begin{array}{l}\text { Other accidents outside } \\
\text { working hours: }\end{array}$} \\
\hline Drowning & 5 & 1 & 1 & 6 & 1 & $14(19)$ \\
\hline Intoxication & 2 & 0 & 2 & 1 & 1 & $6(8)$ \\
\hline Warfare & 0 & 0 & 1 & 0 & 1 & $2(3)$ \\
\hline Traffic accidents ashore & 0 & 0 & 0 & 1 & 1 & $2(3)$ \\
\hline Total & 21 (29) & $8(11)$ & $14(19)$ & $17(23)$ & $13(18)$ & $73(100)$ \\
\hline
\end{tabular}

$\mathrm{OS}=$ ordinary seamen (less than four years of experience at sea); $\mathrm{AB}=$ able bodied seamen (experienced seamen).

these cases basic safety regulations were violated.

Another 24 fatal accidents took place during off duty hours (tables 2 and 3). Five seamen died because of intoxications with either alcohol, narcotics, or methanol and one seaman died because of unintentional intoxication with chloroquine used for malaria prophylaxis. Among the remaining 18, 14 seamen drowned. Twelve drowned in the harbour after having been ashore, one drowned while swimming from the ships' side, and one fell overboard while trying to walk on the ships' rail. In 11 of the 14 drownings, the victims had according to witnesses been under the influence of alcohol and in three cases, no information was available. Two seamen were killed because of warfare in two different incidents and finally, two were killed in traffic accidents while ashore, one of these was inebriated. Thus, alcohol was a contributing factor in 12 of the 18 cases occurring during off duty hours due to other causes than intoxications.

Among the 73 deaths caused by accidents, $17(23 \%)$ were ordinary seamen (with less than four years of experience). For comparison, according to data from the Register of Seafarers, ordinary seamen only made up $9 \%$ of the total crew on board on 1 July 1993.

Twelve seamen committed suicide while on board. The most common mode was hanging with seven cases. Three seamen jumped over board, two of them were most likely psychotic. Finally, one committed suicide by poisoning with carbon dioxide and another took a huge overdose of chloroquine, which was freely available because the ship recently had been in a malarial zone. Two deaths were murder.
In the remaining seven cases, it has not been possible to ascertain the manner of death. In five cases, the crew member was found to be missing at sea, and in one case within a port area, but without any clues as to what had happened. Two of those who disappeared from the ship at sea had been asked to resign in next port of call because of alcohol misuse. Finally, a ship's engineer died according to history because of heatstroke, but no necropsy was performed, and it was thus not possible to exclude other diagnoses.

\section{INCIDENCE OF ACCIDENTS AND OCCURRENCE} OF WORK RELATED NATURAL DEATHS

The incidence and incidence rate ratio for fatal accidents among seamen recorded in the Register of Seafarers was high (table 4). Only accidents occuring after the computerisation of Register of Seafarers in April 1986 are included. Information about fatal occupational accidents ashore in the same period as the study period was obtained from The Danish Labour Inspection Services. A total of 543 fatal occupational accidents among men had been identified during the period 1986-93 giving an incidence of $0.46 / 10000$ personyears. This figure includes all recorded fatal occupational accidents at the workplace. ${ }^{13}$ Traffic accidents among professional drivers are included whereas fatalities at sea (including fishing) are not included in those statistics.

Besides the accidents, five seamen died from work related diseases. Three deaths were due to malaria. A fourth death was the ship's engineer, already mentioned, who probably died due to heatstroke and was thus a work related death. A fifth death was due to unin-

Table 4 Risk for different types of accidents among male seamen included in Danish Maritime Authorities Register of Seafarers signed on merchant vessels in the period from 1 April 1986 until December 1993 compared with the risk of occupational accidents among Danish men in all occupations ashore 1986-93

\begin{tabular}{lllc}
\hline Accident category & $\begin{array}{l}\text { Casualties at sea } \\
(n)\end{array}$ & $\begin{array}{l}\text { Mortality/ } \\
10 \text { 000 seamen/y }\end{array}$ & $\begin{array}{l}\text { Relative risk for } \\
\text { seamen }(95 \% \text { CI })\end{array}$ \\
\hline $\begin{array}{l}\text { Accidents directly related to work } \\
\begin{array}{l}\text { Accidents directly related to work } \\
\text { plus maritime casualties }\end{array}\end{array}$ & 18 & $1 \cdot 73$ & $3 \cdot 72(2 \cdot 3-6 \cdot 0)$ \\
$\begin{array}{l}\text { All accidents except self inflicted intoxications and } \\
\text { traffic accidents ashore }\end{array}$ & 41 & 3.94 & $8 \cdot 48(6 \cdot 2-11 \cdot 6)$ \\
\hline
\end{tabular}

^Including two casualties caused by warfare. 
tentional chloroquine intoxication and therefore was also a death occurring as a consequence of the employment as the chloroquin was taken as malaria prophylaxis. The actual number of work related deaths are thus higher than the figures for fatal accidents only.

\section{MEDICAL CARE ON BOARD}

In case of acute disease or injuries among the crew, a senior deck officer or the captain on board has the responsibility of the treatment and care, as no Danish merchant ships have a doctor on board any more. Danish ships have free access to medical advice by radio. ${ }^{6}$

In total, 84 seamen died while the ship was at sea (tables 1 and 2), but 62 were either lost from the ship, killed instantly, or found dead. Another five seamen died within minutes and 17 were alive for more than half an hour. Finally, eight seamen were taken off the ship but later died. Thus, a total of 25 seamen were in need of medical care beyond first aid.

Seven of the 17 seamen ( $41 \%$ ) who were alive for more than half an hour after trauma or first appearance of disease but died on board were found dead, and thus had not been under constant observation. Four of the seven had apparently tried to get up and were found on the floor of the cabin or the bathroom. The 17 seamen remained alive for a mean of $2 \cdot 3$ days ( 1 hour to $9 \frac{1}{2}$ days) from trauma or first appearance of disease until death. The eight seamen who were taken off the ship were removed at a mean of 1.4 days ( 3 hours to 7 days) after first appearance of disease or occurrence of accident and died at a mean of $6 \cdot 4$ days ( 1 hour to 28 days) after landing.

In the 25 cases, where the sick or injured person was on board for more than half an hour before they died or were taken off the ship, medical advice was sought in 17 cases (68\%). In six cases, advice was not sought and in the remaining two cases, the situation is uncertain. Four of the six cases where no medical advice was sought, were diseases with a good prognosis if treated optimally (malaria, meningitis, pneumonia, and one case of alcohol withdrawal symptoms), but treatment on board the ship would probably not have changed the outcome in the remaining two cases (stroke and acute myocardial infarction). Of the 17 cases where medical advice was sought, in two cases it was not sought before the patient was dying. In another two cases, advice was called for at a critical stage despite the fact that the disease had been known about for more than a week in both cases. In five cases help was called without delay, and in the remaining cases with some delay.

In two cases of malaria, the ship's officer on board had not been advised by the doctor ashore to give antimalarial treatment to patients with fever and recent relevant exposure. Use of acetylsalicylic acid was not advised for any of the patients with acute heart disease.

\section{HEALTH EXAMINATIONS}

All seamen on board Danish ships have to pass a health examination every two years. Among the 53 seamen who died of natural causes, we found 42 of the original health examination forms $(79 \%)$. Nine of the 42 forms $(21 \%)$ had some remarks, and one seaman only had a certificate valid for one year. One had signed on with a falsified health certificate.

Two seamen had apparently not informed the doctor about serious disease including tuberculosis, diabetes, and recent gastrointestinal bleeding. In five of the 20 health examination forms of seamen who died from cardiovascular disease, the condition was known according to the form. Among the remaining 15, another two had well known cardiovascular disease according to other documents, and took daily medicine for it, but this was not mentioned on the form.

\section{Discussion}

Because the shipping companies can get compensation for costs due to accidents, disease, and deaths among the crew they have an economic interest in reporting deaths to the maritime authorities. Few deaths were identified from other sources than the maritime authorities. The material presented is therefore probably complete.

This study only covers problems related to deaths of seamen signed on merchant ships. Death is the ultimate consequence of disease or accident but only represents a few of the cases of disease or accidents occurring in shipping. The results of this study cannot be used to generalise about occupational risks to seamen. It is necessary to take into consideration other data about non-fatal cases of disease and accidents.

Poor medical care on board and poor medical advice from doctors ashore influenced the outcome in some cases although the chances of advanced treatment are poor on a ship at sea. For example, in cases of sudden cardiac arrest, even optimally performed cardiopulmonary resuscitation may be of limited value as there is a lack of access to early defibrillation and early advanced life support. Also, a large proportion of those who died because of disease were found dead. The largest single group of natural deaths consisted of seamen with cardiovascular and cerebrovascular diseases. Primary prevention may be of benefit. Danish seamen smoke much more than nonseamen and more are overweight. ${ }^{14}$ So far, no initiatives specifically directed towards seamen have been taken in Denmark and smoking is completely unregulated in almost all ships. But one treatment should not be forgotten. Acetylsalicylic acid is a simple and very effective treatment for acute myocardial infarction. ${ }^{15}$ Ships' officers in charge of the health service on board as well as doctors giving advice to ships by radio should be aware of this.

The risk of malaria should be known to all sailing in malarial zones. A seaman at sea who has a fever and has recently visited a malarial zone should be treated as having malaria. Severe cases of infectious diseases like pneumonia should be treated with parenterally 
administered antibiotics. Those responsible for health on board should therefore be able to safely give drugs parenterally. But conventional treatment might be insufficient. Legionella bacteria have been shown to be very common in ships' water supplies ${ }^{16}$ and possibly also in ships' air conditioning. ${ }^{17}$ This may be a risk factor as it has recently been shown to be in hospitals. ${ }^{18}$ When sailing in the tropics, the cold water on board reaches temperatures close to the optimal for legionella because the water is stored in tanks at the bottom of the ship, and therefore is the same temperature as the sea water.

The incidence of all fatal accidents except self inflicted intoxications and traffic accidents ashore was $5 \cdot 29 / 10000$ person-years or more than 11 times higher than the mean for all men working ashore in Denmark. The incidence is higher than found in Swedish shipping during the period $1984-8^{4}$ where it was $4 \cdot 4 / 10000$ person-years. A higher proportion of the Swedish seamen work in passenger ships than in Denmark, which may explain some of the difference. In a German study covering the period from 1974 to 1976 the incidence was 9.2/10 000 person-years. ${ }^{19}$ Although the risk for seamen was high compared with other occupations in Denmark, it is lower than among high risk occupations like fishermen where the incidence of fatal occupational accidents recently was found to be $14 \cdot 5 / 10000$ person-years. ${ }^{20}$ This is close to the incidence of fatality of $14.3 / 10000$ person-years found among Australian fishermen ${ }^{21}$ but lower than the incidence among fishermen in Alaska where an extreme incidence of 41.5/10 000 person-years has been found..$^{22}$

Poor systems of work played a part in most of the fatal occupational accidents. Falls on board and falls overboard were the biggest groups in this category. In some of the cases use of safety equipment such as safety belts and life jackets could possibly have changed the outcome although disease, alcohol, and drugs may have had important influences in some of the cases. Setting out pilot ladders alone was found to be a risky procedure. In ships where setting out pilot ladders gives a risk of falling overboard, the procedure should be done by two people. The fatal accidents where seamen were swept over board, could in at least some of the cases have been prevented. The ships were most likely not fit at departure for a storm which later forced the crew out on deck in very bad weather. Use of life jackets and safety lines could have improved the chance of survival. Working with moorings and hawsers not only cause fatalities but is also a known cause of many accidents. ${ }^{23}$ Suffocation in holds and tanks is a well known risk and international guidelines made by the International Maritime Organisation already exist. ${ }^{24}$ More effort has to be made to implement these guidelines on all levels. Lack of sufficient planning was an important factor in most of the accidents. They can only be prevented as a part of broader safety awareness programmes at sea.

Alcohol intoxication was an important risk factor for fatal accidents during off duty hours.
The very frequent deaths caused by drowning in harbour areas, of in most cases young and inexperienced seamen returning from public houses ashore, may be prevented by introducing a change of attitude. As all the accidents happened when the seaman was alone one message should be that a drunken shipmate should never be left alone ashore.

Mental instability or overt psychiatric disease were a characteristic of several of the seamen who committed suicide or disappeared from the ship. The crew on board had difficulties in dealing with that kind of problem. The basic health education of ships' officers should include knowledge about psychiatric diseases and how to handle them. Some of those who disappeared from the ship may have had calentura: a behavioural phenomenon known for centuries, the predominant symptom being an irresistible impulse of seamen to jump into the sea from their vessels. ${ }^{25}$

The fact that some seamen were found dead despite the fact that their diseases were known about on board ship may indicate that nursing is a field where the basic health education of ships' officers should be improved. Medical advice was not sought in all cases despite abundant time to do so. In several cases medical advice was not sought before a very late stage of disease, in some cases not before the patient actually had cardiorespiratory failure. This indicates a need for improved training of ships' officers in the rational use of medical advice by radio. Also, doctors giving medical advice to ships should be trained in the special circumstances on board a ship at sea and should also have knowledge of the medical possibilities on board. For example, fatal cases of malaria could possibly be avoided. Within the European Community it is now mandatory that doctors giving medical advice to ships have special training. ${ }^{26}$

The evaluation of the health certificates showed that important health information in some cases was withheld by the seamen at the health examination. This gives these health examinations less value. The basic clinical examination now performed in Denmark misses many cases of cardiovascular diseases. On the other hand, introducing more sensitive examinations would also exclude many middle aged and older seamen from their occupation with few alternatives ashore, possibly creating new health problems.

This study was supported by grants from Sygekassernes Helsefond and Danish Maritime Occupational Health Service, which is gratefully acknowledged. I thank Ms Gyda Pedersen at the Danish Maritime Authority and the staff of the Danish Shipowners Accident Insurance Association for their invaluable assistance. Dr Annie Vesterby, Department of Forensic Medicine, University of Aarhus is thanked for assistance in the classification of manner and causes of death.

1 Arner O. Dodsulykker blant sjemenn. Oslo, Bergen, Tromsø: Unversitetsforlaget, 1980. (In Norwegian with English summary.)

2 Bang J, Fischerman M, Franck C, Lyngenboe $O$, Nielsen A, Weihe P. Dodsulykker blandt søens folk. In: Jepsen JR, Christiansen JM, eds. Sefarts- og fiskerimedicin. Esbjerg: Sydjysk Universitetscenter, 1988:143-69. (In Danish with English summary.)

3 Cramm M, van Damme P, van Damme J, van Sprundel M, Meheus A. Occupational accidents among seafarers. In Gardner AW, ed. Proceedings of the Second International 
Symposium on Maritime Health. Antwerpen: 1993: 238-40.

4 Larsson TJ, Lindquist C. Traumatic fatalities among Swedish seafarers 1984-8. Safety Science 1992;15: 173-82.

5 Brayley NF. A review of three years experience of medical advice to seafarers by the casualty officer, Royal Naval Hospital Plymouth, via Portishead Radio (W/T Medico Portishead). $¥ R$ Nav Med Serv 1980;66: 93-106.

6 Strange-Vognsen HH, Knudstorp N. Radio medical advise-the Danish experience. $\mathcal{F} R$ Nav Med Serv 1995; 81:12-5.

7 Oliver PO. A study of the causes of medical attendance aboard British merchant ships. Public Health 1981;95: 74-81.

8 Danmarks Statistik. Statistisk tiårsoversigt 1994. Copenhagen: Danmarks Statistik, 1994.

9 Arbejdsmarked. In: Statistisk Arbog 1994. Copenhagen: Danmarks Statistik, 1994;162-5.

10 Dean AG, Dean JA, Coulombier D, Brendel KA, Smith DC, Burton AH, et al. Epi Info, Version 6.02. Atlanta, Georgia: Centers for Disease Control and Prevention, 1994.

11 Greenland S, Robins JM. Estimation of a common effect parameter from sparse follow-up data. Biometrics 1985; 41:55-68.

12 Danish Maritime Authority. Accidents at sea 1993. Copenhagen: DMA, 1994.

13 The Danish Labour Inspection Service. The functions of the Danish Registry of Occupational Injuries. Copenhagen: The Danish Labour Inspection Services, 1991.

14 Hansen HL, Dahl S, Bertelsen B, Brix J. Lifestyle, nutritional status and working conditions of Danish sailors. tional status and working conditions of Danist

15 Yusuf S, Lessem J, Jha P, Lonn E. Primary and secondary prevention of myocardial infarction and strokes: an update of randomly allocated, controlled trials. $f$ Hypertens Suppl 1993;11:S61-73.

6 Herrmann R, Katz A, Sammann A. Legionalla species on board merchant marine vessels. In: Gardner AW, ed. Proceedings of the Second International Symposium on Maritime Health. Antwerp: 1993;313-24.

17 Depatment of Transport. Contamination of ships' air conditioning systems by legionella bacteria. London: HMSO, 1986 .

18 Darelid J, Bengtsson L, Gästrin B, Hallander H, Löfgren S, Malmvall B-E, et al. An outbreak of legionnaires' disease in a Swedish hospital. Scand $\mathcal{F}$ Infect Dis 1994;26:417-25. 19 Vrcelj J. Todesfalle in der seeschiffarht. In: Die Unfalle an bord von deutchen Seescfiffen und ihre atiologie von 1974-76. Hamburg: University of Hamburg, 1981;127-9.

20 Jensen O. Analyse af anmeldte fiskeriulykker til Søfartsstyrelsen 1988-92. Esbjerg: South Jutland University Centre, 1994

21 Driscoll TR, Ansari G., Harrison JE, Frommer MS, Ruck EA. Traumatic work related fatalities in commercial fishermen in Australia. Occup Envirom Med 1994:51:612-6.

22 Schnitzer PG, Landen D, Russel JC. Occupational injury deaths in Alaska's fishing industry, 1980-88. Am F Public deaths in Alaska's fishing

23 Vrcelj J. Die Unfalle an board von deutschen Seeschiffen und ihre Atiologie von 1974-6. Hamburg: University of Hamburg, 1981 .

24 International Maritime Organisation. Code of safe practice for solid bulk cargoes. London: IMO, 1991.

25 Macleod AD. Calenture-missing at sea? Br 7 Med Psychol 1983;56:347-50.

26 The Council of the European Communities. Council Directive 92/29/EEC on the minimum safety and health Directive $92 / 29 /$ EC requirements for improved medical treatment on board
vessels. Bruxelles: CEC 1992 . 